\title{
Graptemys flavimaculata Cagle 1954 - Yellow-Blotched Sawback, Yellow-Blotched Map Turtle
}

\author{
Will Selman ${ }^{1}$ and Robert L. Jones ${ }^{2}$ \\ ${ }^{1}$ Rockefeller Wildlife Refuge, Louisiana Department of Wildlife and Fisheries, \\ 5476 Grand Chenier Hwy, Grand Chenier, Louisiana 70643 USA [wselman@wlf.la.gov]; \\ ${ }^{2}$ Mississippi Department of Wildlife, Fisheries, and Parks, Mississippi Musuem of Natural Science, \\ 2148 Riverside Drive, Jackson, Mississippi 39202 USA [bob.jones@mmns.state.ms.us]
}

\begin{abstract}
Summary. - The Yellow-blotched Sawback, Graptemys flavimaculata (Family Emydidae), is a small to medium-sized riverine species endemic to the Pascagoula River drainage of southeast Mississippi, USA. Sexual dimorphism is pronounced, with adult females attaining more than twice the length and ten times the mass of adult males. Although the species is locally abundant, populations are threatened by habitat destruction, collection for the pet trade, invasive species, water quality degradataion, and other human impacts. Previously listed as Endangered on the IUCN Red List, the species has recently been downlisted to Vulnerable due to improved population estimates, newly discovered localities, and improved water qualities leading to some recovered populations. It remains Threatened because of its small range, large number of potential threats, and moderately severe declines in the largest population.

Distribution. - USA. Restricted to the Pascagoula River drainage of southeastern Mississippi.

Synonymy.-Graptemys flavimaculata Cagle 1954,Graptemys oculiferaflavimaculata,Malaclemys flavimaculata.

SubSPECIES. - None recognized.

STATUS. - IUCN 2011 Red List Status: Vulnerable (VU) (A2bce+4ce) (assessed 2010); CITES: Appendix III (Graptemys spp.; USA); US ESA: Threatened.
\end{abstract}

Taxonomy. - The Yellow-blotched Sawback (Graptemys flavimaculata) was described by Cagle (1954) from individuals collected from Mississippi, USA. The holotype was a juvenile male collected from the Pascagoula River, $13 \mathrm{mi}$ (ca. $21 \mathrm{~km}$ ) southwest of Lucedale, George County, Mississippi (Tulane University \#14798). Cagle described this species as a member of the narrow-headed complex, which included the ringed sawback (G.oculifera) of the Pearl River and the black-knobbed sawback $(G$. nigrinoda) of the Mobile River Basin. No subspecies of $G$. flavimaculata have been described.

Recent molecular analyses by Weins et al. (2010) confirmed the three 'sawback' species (G. flavimaculata, G. oculifera, and G. nigrinoda) as a well-defined clade;

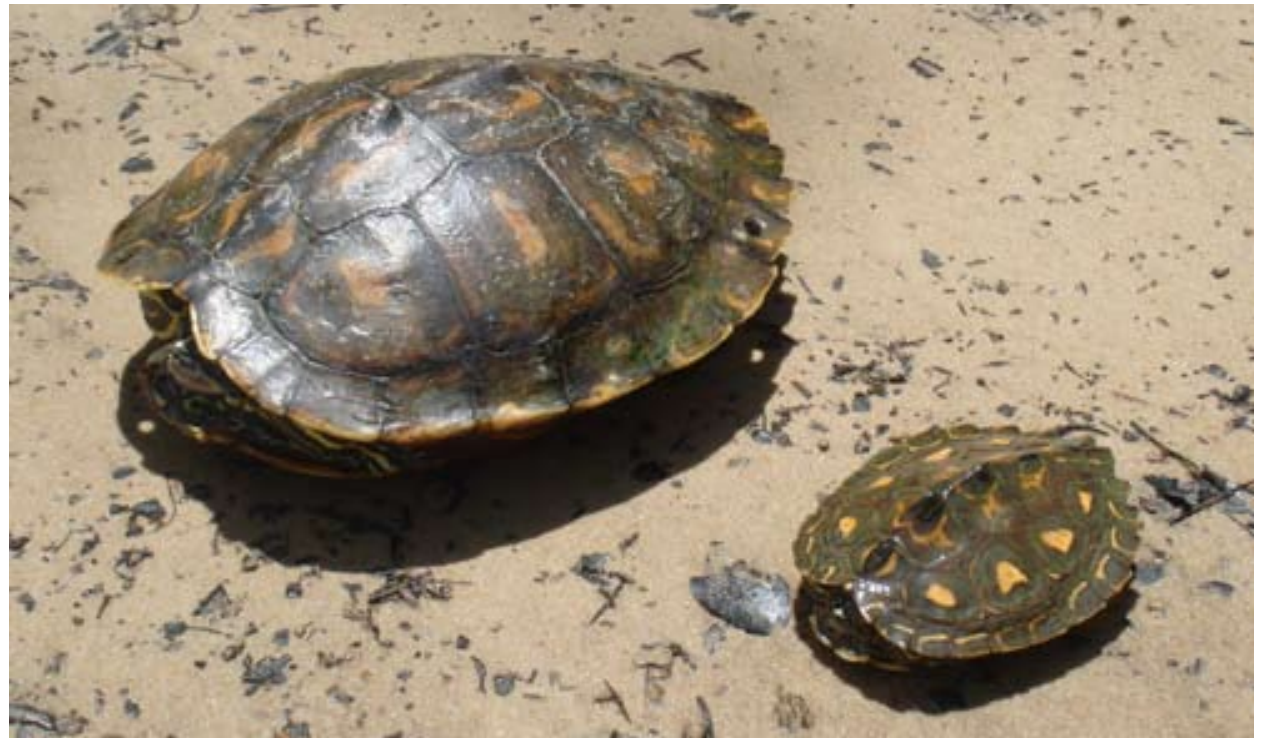

Figure 1. Adult female (left; $20.6 \mathrm{~cm} \mathrm{SCL}, 1400 \mathrm{~g}$ ) and adult male (right; $10.0 \mathrm{~cm} \mathrm{SCL,} 130 \mathrm{~g}$ ) Graptemys flavimaculata from the lower Pascagoula River (Jackson County, Mississippi). Adult females can attain twice the size and 10 times the mass of adult males. Photo by Will Selman. 


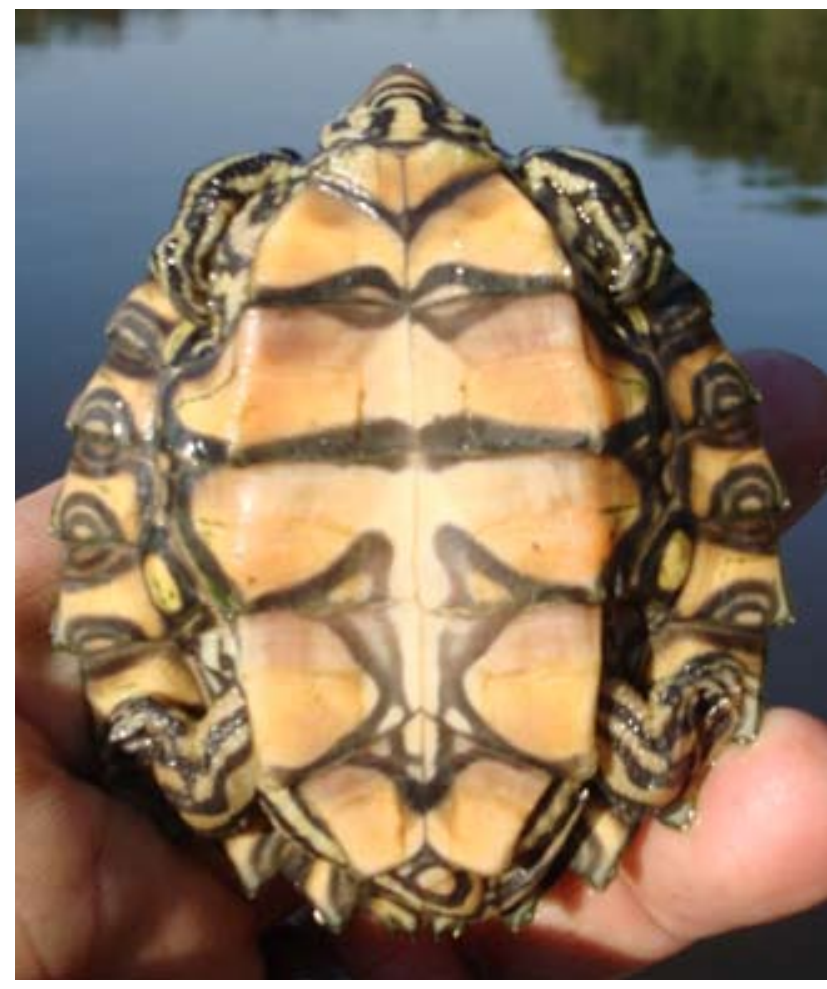

Figure 2. Plastral markings on a male Graptemys flavimaculata from the lower Pascagoula River, Jackson Co., Mississippi. Photo by Will Selman.

they are distinguishable by morphology and shell patterns, but do not exhibit extremely divergent mtDNA genotypes (Lamb et al. 1994). The same three species, along with $G$. ouachitensis, G.pseudogeographica, G.versa, and G.caglei, form the Graptemys pseudogeographica species complex of the genus. Graptemys oculifera and G. flavimaculata were well supported as sister taxa (Lamb et al. 1994 ), but in recent analysis using both nuclear and mitochondrial genomes, Weins et al. (2010) found G. nigrinoda to be the sister species to G. flavimaculata. The latter study, however, noted that many of the relationships within the Graptemys genus were unresolved and needed additional study.

Phylogeography of G. flavimaculata was examined by Selman (2010), using microsatellite loci optimized for the species according to Selman et al. (2009). Genetic distance was highly correlated to geographic distance between sites,
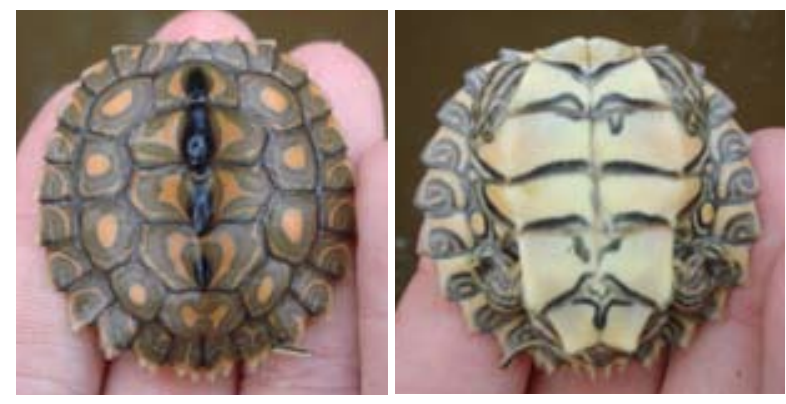

Figure 4. Dorsal (left) and ventral (right) profiles of a recently hatched Graptemys flavimaculata from the Leaf River, Forrest Co., Mississippi. Photos by Will Selman.

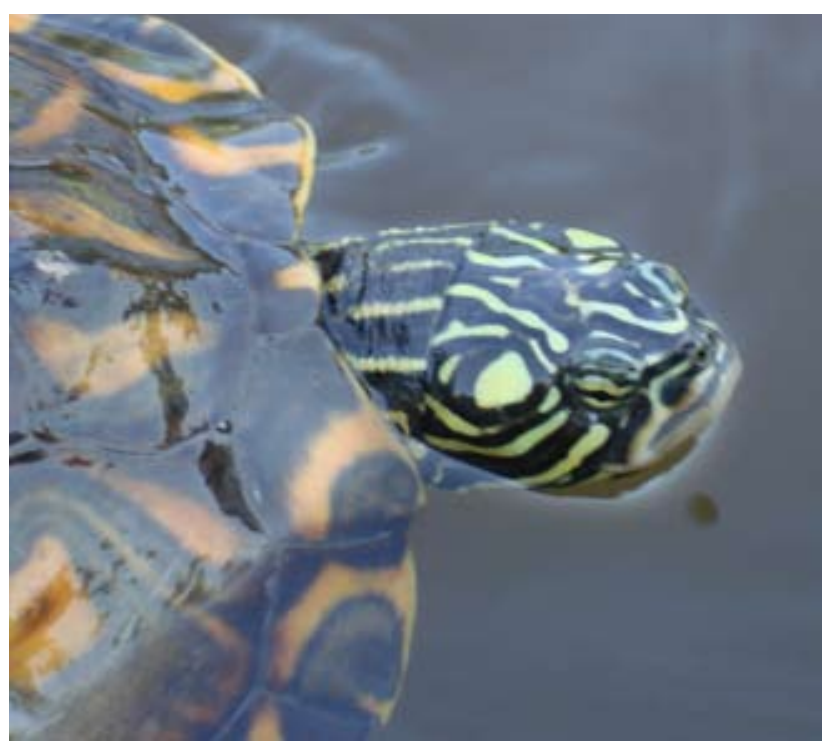

Figure 3. Head markings of a female Graptemys flavimaculata from the lower Pascagoula River, Jackson Co., Mississippi. Photo by Will Selman.

with the exception of the Escatawpa River site. Several analyses found that most of the genetic variation was partitioned within rather than among sites. However, despite the relatively small contiguous river distances separating mainstem river sites, all of the pairwise genetic differentiation values (as measured by $F_{S T}$ ) were significant, and most sites possessed one or more private alleles. Notably, $F_{S T}$ levels for the Escatawpa River site were larger $(0.030-0.047)$ relative to other mainstem riverpopulation comparisons, which likely reflect this population's historical isolation. Selman (2010) suggested that the Escatawpa River population should be treated as an Evolutionarily Distinct Unit due to its genetic uniqueness relative to other mainstem populations.

Description. - Graptemys flavimaculata is a small to medium-sized turtle (males to $119 \mathrm{~mm}$ midline carapace length [CL],225 g; femalesto $214 \mathrm{~mm}$ midlineCL, $1675 \mathrm{~g}$;W.Selman, unpubl. data). The shell is moderately high-domed, possesses a median keel, and the edge of the carapace is serrate (Fig. 1). Pleural scutes $1-4$ usually have yellow to yellow-orange blotches, but these markings can be quite variable, and may
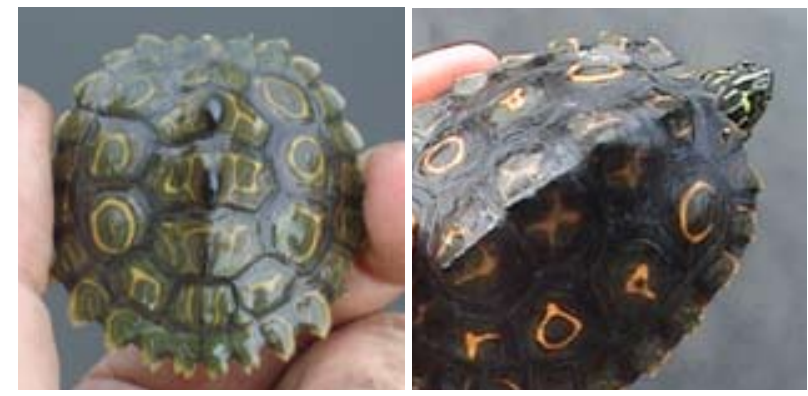

Figure 5. A post-hatchling (left) and juvenile female (right) Graptemys flavimaculata from the Escatawpa River, Jackson Co., Mississippi, exhibiting a ringed scute pattern, similar to the ringed sawback (G.oculifera). This population appears to be highly variable in pleural scute patterning, as well as having a higher incidence of rings. Photos by Will Selman. 


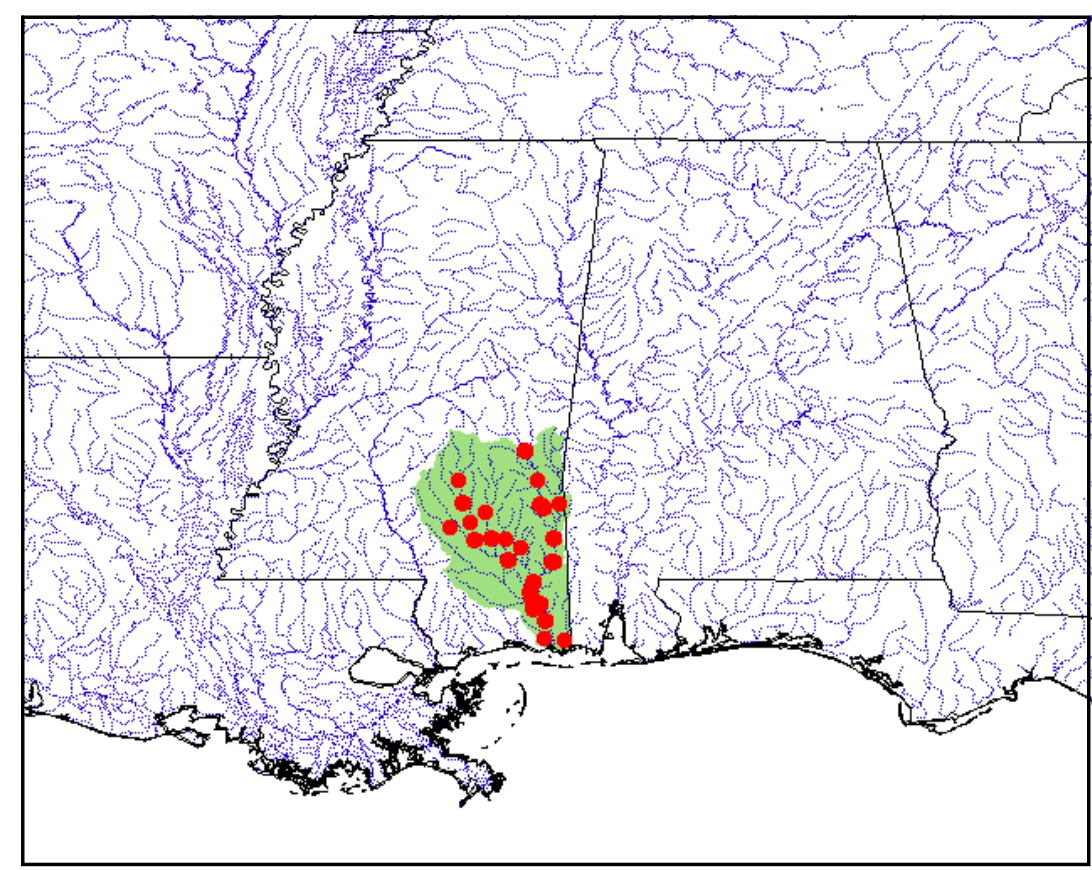

Figure 6. Distribution of Graptemys flavimaculata in Mississippi, USA. Red dots = museum and literature occurrence records of native populations based on Iverson (1992), plus more recent and authors' data; green shading = projected distribution based on GIS-defined hydrologic unit compartments (HUCs) constructed around verified localities and then adding HUCs that connect known point localities in the same watershed or physiographic region, and similar habitats and elevations as verified HUCs (Buhlmann et al. 2009), and adjusted based on authors' data. The Escatawpa River is the furthest southeastern marked locality.

include broken blotches, crescents, or completely formed rings similar to those of the ringed sawback, G. oculifera (Ennen et al. 2010; W. Selman, pers. obs.). The marginal scutes usually have a yellow or yellow-orange semi-circle or bar. These patterns and colors often fade with age, particularly in adult females. The median keel of males is composed of laterally compressed spines on the first, second, and third vertebral scutes, but are less prominent and ridge-like in adult females. The plastron is predominantly cream to yellow in color with black markings on the plastral seams (McCoy and Vogt, 1987; Fig. 2). Ground color of the head and limbs is black with yellow or yellowish-green lateral head and neck stripes. The highly variable head pattern consists of a rectanglular, circular, or triangular postorbital blotch with usually two wide, yellow, lateral neck lines extending posteriorly from the orbit (Fig. 3). Additionally, a dorsal line extends on the top of the

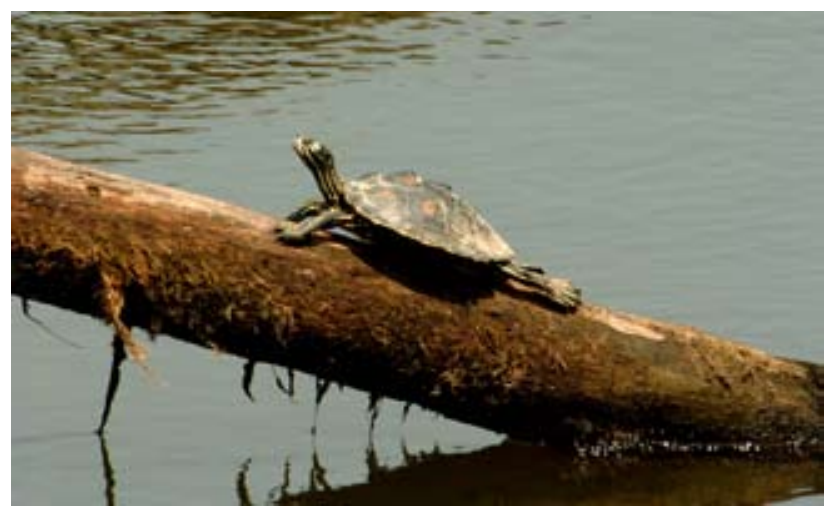

Figure 7. Basking Graptemys flavimaculata on the Leaf River, Forrest Co., Mississippi. Photo by Peter V. Lindeman. head between the two postorbital blotches to a point above the nares.

Adult females can be over twice the length and almost ten times the mass of adult males, with significant femalebiased sexual size dimorphism observed in all populations observed(W.Selman, unpubl.data).Females also have higher domed shells and proportionally broader heads, than males. However, the head widths of G. flavimaculata females are not as conspicuous as adult females of the G. pulchra clade. Males have longer tails with the vent posterior to the edge of the carapace, well developed carapacial spines, and longer foreclaws in comparison to female G. flavimaculata.

Hatchling coloration resembles that of adults, but is generally more vivid and contrasting (Fig. 4). Hatchlings are quite small (34.3 mm carapace length, $29.9 \mathrm{~mm}$ plastron length; Brauman 1995) and by their first year, turtles are nearly as wide as they are long $(44 \mathrm{~mm} \mathrm{CL}, 44 \mathrm{~mm}$ carapace width, $37 \mathrm{~mm}$ plastron length, $15 \mathrm{~g}$; W. Selman, unpubl. data), and have a completely serrate carapace edge, as well as a pronounced vertebral keel that is not as laterally compressed as in adult males. The dark plastral markings of hatchlings often cover more area than in adults. The size of the head of hatchlings is also proportionally larger than in adults.

There are notable differences among different $G$. flavimaculata populations. Turtles in the lower reaches of the Pascagoula River attain a significantly larger size than individuals in the upper reaches of the drainage (W. Selman, unpub. data). Thick, "donut-like" rings, as noted in the holotype (see Figs. 3 and 5 in Cagle 1954), have been found in all sampled populations, but are uncommon. Thin 
rings on the pleural scutes are virtually absent in northern populations, but they are more common in downstream populations, particularly within the Escatawpa River (Fig. 5 ; W. Selman, unpubl. data). Thus, some individuals could be misidentified as G.oculifera if the collection locality was unknown.

Killebrew (1979) compared the osteology of G. flavimaculata and G. nigrinoda, with G. flavimaculata having: a broad anterior projection of the frontal (more narrow in G. nigrinoda), a broad rostral projection of the basisphenoid (more narrow in G. nigrinoda), the absence of the projection of the palatine process of the premaxilla (G. nigrinoda possesses this projection), and a more steeply sloped carapace (more flattened carapace in G.nigrinoda).Ennen etal.(2010) further delineated G. flavimaculata and G. oculifera using molecular and morphological characters from preserved specimens. As with Lamb et al. (1994), they found limited mitochondrial differentiation but significant morphological variation; G. flavimaculata had more yellow pigmentation on the carapace, a longer postorbital blotch, yellow dorsal neck lines that connect to the postorbital blotches, and a broader interorbital line relative to G. oculifera.

Distribution. - Graptemys flavimaculata is found only in large rivers to medium sized creeks in the Pascagoula River system of Mississippi, USA (Fig. 6). The species is also associated with oxbow lakes and cypress ponds that are found within the river floodplain (Jones 1996). Documented localities are in the Pascagoula and Chickasawhay rivers (Cagle 1954), Leaf River, Tallahala Creek, Red Creek (Cliburn 1971), Escatawpa River (P. Floyd, pers. comm.; Selman and Qualls 2009a), Bouie River, and Black Creek (Lindeman 1998). Recently, several new drainages were found to harbor G. flavimaculata, including Bluff, Bogue Homa, Bouie, Bucatunna, Gaine's, Okatoma, and Thompson's creeks (Selman and Qualls 2009a). However, G. flavimaculata does not occur in habitats that appear suitable in middle to upper portions of Black Creek, Red Creek, and the Escatawpa River (Selman and Qualls 2009a). Downstream limits for $G$. flavimaculata were generally 13.5 river km north of the mouth of the Pascagoula River while some individuals have been captured as far south as the mouth of the Pascagoula River, near U.S. Hwy 90 (Tom Mann, pers. comm.); these individuals likely represent vagrants rather than a viable population. There are also unsubstantiated reports of individuals washing up on Gulf beaches and at least one specimen, subsequently lost, was found on Horn Island, assumed to have been washed out during Pascagoula River flooding (Tom Mann, pers. comm.).

Populations of $G$. flavimaculata in the Escatawpa River and Bluff Creek appear to be disjunct from the main population within the lower Pascagoula River because of unsuitable brackish marsh habitat (W. Selman, pers. obs.). The extent of marshland in the lower Pascagoula River may have increased due to the dredging of shipping channels in the East Pascagoula River and thus, may have broadened the gap between the Pascagoula River and Escatawpa River populations.
The species was documented to occur in Key Biscayne, Florida, in 1976 (Bader 1976), likely from pet trade individuals. Later surveys by Krysko et al. (2010) did not document the persistence of G. flavimaculata on this island.

Habitat and Ecology. - Graptemys flavimaculata is most abundant in large to medium sized rivers that provide open canopies for abundant sunlight and basking opportunities. These larger rivers often have abundant deadwood snags for basking sites (Fig. 7), nesting sites on sandbars, and abundant prey items. However, medium to large creeks (15-30 m wide) are also inhabited, primarily in bends of the stream that offer similar 'big river' habitat characteristics (Selman and Qualls 2009a). Graptemys flavimaculata are riverine specialists and have not been observed in non-flowing lakes or ponds except for oxbow lakes and cypress ponds that border the Pascagoula River (Jones 1996). Further, Selman and Qualls (2009a) found no individuals within the non-flowing, lake sections of the lower Bouie River, which were created by gravel mining operations, but individuals were seen in historical flowing river channels between these lakes. Also, few individuals were noted in the $3.8 \mathrm{~km}$ channelized and de-snagged portion of the Leaf River adjacent to Hattiesburg, compared to unaltered portions of the Leaf River upstream and downstream of Hattiesburg.

Graptemys flavimaculata also appears to be sensitive to industrial and municipal discharges. In 1986, Lovich found that $G$. flavimaculata and $G$. gibbonsi were absent below a paper mill discharging point on the Leaf River, but were abundant in the river upstream from the pollution source (Ernst and Lovich 2009). Ironically, 15 years later, Selman and Qualls (2009a) found this locality had one of the highest densities of G. flavimaculata and G. gibbonsi in the Pascagoula River system. Municipal effluents from Hattiesburg also appear to have affected G. flavimaculata populations, as only two individuals were observed basking in a 1.5 river km section of the Leaf River between two sewage treatment lagoons and outflow sections (Selman and Qualls 2009a). In comparison, it is not uncommon to observe up to 20 basking G. flavimaculata within the same river distance upstream of this impacted river section.

The growth of G. flavimaculata is rapid during the first five years of life for both males and females (Jones 1994). However, by year three or four, one can usually discern the sex of the individual, due to the more rapid growth of juvenile females and the onset of adult female characteristics (i.e., larger head and shorter tail with vent anterior to carapacial edge; W. Selman, pers. obs.). Males usually attain a plastron length of $80 \mathrm{~mm}$ by their fifth year, with females usually $95 \mathrm{~mm}$ at year five (Jones 1994). Following 5-7 years of growth, it becomes increasingly difficult to age turtles based on scute annuli due to the sloughing of the scute present at hatching. The minimum age at maturity for males is 4 yrs and for females is $10 \mathrm{yrs}$ in the lower Pascagoula population (Jones 1994).

Feeding has been noted on multiple occasions where individuals appear to be grazing on algae and/or macroin- 
vertebrates in the algae that grows on submerged deadwood, suggesting that this species may be omnivorous (Selman and Qualls 2008a). Seigel and Brauman (1994) found that sponges and aquatic insect larvae are important foods for the species in the lower Pascagoula River. Adult females were also found to eat native clams (Mytilopsisleucopheata), most likely due to their larger heads and associated musculature. Gastrointestinal parasites were examined by Steinauer and Horne (2002) from turtles collected from the Pascagoula River. Eight species of enteric helminths were found to be present and the yellow-blotched sawback was a new host record for all species. Five of the eight species present were presumed to be through an intermediate mollusk host and none were found to produce any negative pathology.

Graptemys flavimaculata is primarily diurnal. Basking, which is the most common observable activity, occurs from early morning to evening and in all months of the year (Moore 2003; Selman and Qualls 2011). Sometimes turtles stack upon one another and they may bask up to several meters above the water surface (Floyd 1973). While researching this topic in the lower Pascagoula River, Moore (2003) found that hourly basking frequencies for G. flavimaculata were highly variable depending on the season and time of day. Graptemys flavimaculata basks in higher numbers in spring and fall than in winter and summer. During the spring, females basked at a higher frequency than males, presumably to accelerate egg development, and both exhibited a unimodal pattern with activity peaking around 1230 hrs. During the summer, females had a bimodal basking pattern with mid-morning and mid-afternoon peaks, while males had a unimodal basking pattern with activity peaking around $1200 \mathrm{hrs}$. Males basked more frequently than females in the fall, which coincides with their gonadal growth; both exhibited a unimodal basking pattern peaking at $1245 \mathrm{hrs}$. Moore and Seigel (2006) also found that human activity could have a dramatic impact on turtle basking behavior. On 65 of 199 occasions, a passing boat disturbed one or more individuals from their basking location. The number of turtles vacating their basking site depended significantly on the type of disturbance with fisherman (74\%) and speedboats (67\%) disturbing considerably more basking turtles. Females were also more likely to leave their basking location than males. Lower Pascagoula River turtles are disturbed much more frequently than other populations (Selman 2010), which could potentially alter physiological processes in this population, especially reproduction.

Recently, Selman and Qualls (2011) documented the basking ecology of an upstream population of G. flavimaculata in the Leaf River, which was minimally disturbed relative to the population studied by Moore (2003). Mean basking time varied throughout the year for the sexes (females, 42.8 min; males, $38.4 \mathrm{~min}$; juveniles, $23.5 \mathrm{~min}$ ), with females basking significantly longer than juveniles, but not males; maximum basking time observed was $464 \mathrm{~min}$ by a male G. flavimaculata. Basking duration also varied by month and by time of emergence during the day. Longer basking durations were observed during the spring relative to the summer/fall, while individuals basked longer if they emerged during the morning compared to midday/afternoon. During the spring, a unimodal pattern of basking was observed with peak basking observed at midday, a bimodal pattern was observed during the summer (peaks in the morning and late afternoon), and a less distinct pattern was observed during the fall. Male basking was significantly correlated to log temperature, while females showed significant relationships to log, ambient air, and water temperatures. Females used larger basking structures (i.e., logs) compared to males and juveniles. Further, $6.6 \%$ of the monitored individuals were disturbed by natural events (i.e., flying birds, other turtles), while $4 \%$ were disturbed due to human disturbances not associated with researchers. Additionally, interspecific and intraspecific basking competition has been documented with this species (Selman and Qualls 2008b; Selman and Qualls 2011), as well as leeches detaching from turtles while basking (Selman and Qualls 2009b).

Much of what is known about home range, movements, and habitat characteristics was studied in the lower Pascagoula River population by Jones $(1994,1996)$. Mean male home range was 1.12 ha (range $0.29-2.02$ ha), with a mean home range length of $1.8 \mathrm{~km}$ (range $0.18 \mathrm{~km}-5.9 \mathrm{~km})$. Mean female home range was 5.75 ha (range $0.34-13.88$ ha), with a mean home range length of $1.5 \mathrm{~km}$ (range $0.23-2.85$ $\mathrm{km})$. Most turtles were associated with the outer cutbank, where the river was deeper and had a higher abundance of deadwood for basking. Turtles remained relatively sedentary from June-October, except for female movements associated with nesting, but movements increased during the spring and fall. Males were noted in shallower water, slower current speeds, closer to the river bank, and were near more emergent deadwood snags. Females were found farther from the bank than males, in deeper water and faster current speeds, and associated with fewer deadwood snags, presumably due to their better swimming ability. Some individuals had high fidelity to small stretches of river that were usually on one side of the river; many turtles were recaptured on the same logs where they were originally captured. Alternatively, both sexes were also noted to have complex seasonal movement patterns, with some movements associated with flood events; during flooding, individuals would move away from the main river channel to accessory channels or associated cypress/oxbow ponds.

Courtship of G. flavimaculata occurs underwater and the male approaches the female from the front with neck extended (Wahlquist 1970; W. Selman, pers. obs. of captive specimens). The male then strokes or quickly vibrates the dorsal parts of his forelimbs/claws on the side of the female's face, while simultaneously quickly bobbing his head. Wahlquist (1970) also noted the female stroking the male in a similar fashion.

Nesting occurs primarily on sandbars between mid-May and early August (Horne et al.2003). Females nest throughout the day (0900-1915 hrs), but nesting peaks around 1500-1700 hrs (48\% of observed nesting attempts, Moore and Seigel 
2006). Females often wait for lengthy periods (average 160 $\pm 95.6 \mathrm{~min}$ ) before emerging onto sandbars to nest (Moore and Seigel 2006). Total nesting time for females was 34.6 $\pm 11.5 \mathrm{~min}$ (range 22-60 min), which is very fast compared to other emydid species (Moore and Seigel 2006). These authors also suggested that the short nesting duration by females could be an attempt to minimize exposure to human disturbances, since nesting females only had a $19 \%$ chance of successfully completing nesting without disturbance once they committed to emerging onto a sandbar.

Much of what is known about the reproductive biology of G. flavimaculata is from Horne et al.(2003). Gravid females in the lower Pascagoula River were found from mid-May to late July - early August (mean reproductive season of 80-87 days) with clutch size averaging 4.7 eggs. The mean CL of gravid females was $19.1 \mathrm{~cm}$ (smallest gravid female was $15.7 \mathrm{~cm}$ ) with a significantly positive correlation between clutch size and female size. Only 6 of 37 (16.2\%) females that were captured multiple times within the same season were known to produce multiple clutches. Additionally, few females were found to be gravid in multiple seasons (22.2\%) and most were never found while gravid (40.7\%), whereas females in the northern portions of the range have multiple clutches per season (R. Vogt, pers. comm. in Horne 2003, W. Selman, unpubl. data).

The eggs of G. flavimaculata are small, with a creamy white and slightly pliable shell. Mean egg size is 36.8 x 22.9 $\mathrm{mm}$ (wild nests; Brauman 1995), while mean egg mass is $15.0 \mathrm{~g}$ (captives; Ewert and Iverson, unpubl.data). Graptemys flavimaculata is believed to have temperature-dependent sex determination type TSD-1a (high temperatures produce females; low temperature produce males), with the pivotal incubation temperature being $29-30^{\circ} \mathrm{C}$ (Hertwig 2001, as cited in Ernst and Lovich 2009).

Hatching and nest success were studied by Horne (1999) and Horne et al. (2003) in the lower Pascagoula River population. Of 55 unprotected nests, only six successfully hatched $(10.9 \%)$, while the rest were destroyed by predators $(61.8 \%)$ or flooding $(27.3 \%)$. Additionally, over 1500 nests were preyed upon from 1993-97. Some of the noted nest predators were the fish crow (Corvus ossifragus), imported fire ants (Solenopsis invicta), and speckled kingsnakes (Lampropeltis getula, Brauman and Fiorillo 1995); other suspected predators included the raccoon (Procyon lotor) and the feral pig (Sus scrofa). Percentage of eggs that hatched from successful nests in the wild varied from $56.1-82.8 \%$. Females also selected non-vegetated areas of sandbars over vegetated areas. Nests that were in vegetated areas, particularly areas with nonnative vegetation, had lower temperatures of the nesting substrate (Horne 1999). In 2007-08, many hatchling $G$. flavimaculata were observed at multiple sites throughout the Pascagoula River drainage in comparison to 2005-06. Higher numbers of hatchlings observed may have been due to 1) three consecutive dry years following Hurricane Katrina, which may have decreased flood-associated nest mortality and/or 2) lower numbers of nest predators due to high mortality during flooding/surge events associated with Hurricane Katrina (W. Selman, pers. obs.).

Very little is known on reproductive and nesting biology in other portions of the range of G. flavimaculata. Females from upstream populations are significantly smaller than those from the lower Pascagoula River and likely reach maturity at a smaller size (W. Selman, unpubl. data). Nesting has not been observed at upstream sites, but multiple turtle tracks (presumably female G. flavimaculata) have been found on large sandbars; the lengths of these tracks were extensive and females appeared to search for lengthy periods for the proper nest site (W. Selman, pers. obs.). This is in stark contrast to the short nesting time of females in the lower Pascagoula River documented by Moore and Seigel (2006) where they are more subject to human disturbance while nesting.

Steroid hormones have been investigated in G. flavimaculata, primarily from the lower Pascagoula population (Shelby et al. 2000; Shelby and Mendonça 2001; ShelbyWalker et al.2009); the primary focus of these studies was to determine the effects of dioxin effluents from a paper mill on downstream populations (lower Pascagoula River) vs. a reference population (Chickasawhay River). For females, peak estrogen $\left(E_{2}\right)$ levels in the lower Pascagoula River population occurred in spring (May and June), associated with follicular development. There was no difference in seasonal $E_{2}$ or testosterone $(T)$ levels among the two sites. However, when compared to other species of turtles, $E_{2}$ levels for $G$. flavimaculata females were considerably lower. Females from the reference site produced a second clutch more often than the lower Pascagoula River population $(50 \%$ vs. 17\%). Testosterone levels for males were found to peak in the fall (September and October), and were associated with gonadal development. However, $T$ levels were found to be lower in males from the Pascagoula River population relative to males from the Chickasawhay population. $E_{2}$ levels for $10 \%$ of males in the lower Pascagoula River population were found to be similar to female levels. Shelby et al. (2000), Horne et al. (2003), and Shelby-Walker et al. (2009) attributed these abnormal levels and lower fecundity to the presence of dioxin (TCDD) from a paper mill discharge upstream.

The persistence of toxic contaminants in $G$. flavimaculata tissue was analyzed by Kannan et al (2000). Some 90-99\% of the toxic contaminants found were PCB's, but these levels were 100-1000 times less than the levels reported for other turtle species from highly contaminated sites. Additionally, total levels of contaminants for the lower Pascagoula River turtles were not significantly higher than turtles that were collected from the Leaf River, but different compounds were found to be present at higher levels at different sites. Shelby-Walker et al.(2009) also found that total contaminants (PCBs, PCDFs, PCDDs) did not differ between an impacted, downstream site and a reference site upstream from a pulp mill.

Longevity is potentially $30+$ years for males and $50+$ years for females from the lower Pascagoula River population (Selman and Qualls 2005, 2006); many of the oldest 
individuals examined had lost much of the carapace coloration and had many scratches and areas of shell erosion on the carapace and plastron (W. Selman, pers. obs.). Several individuals exhibited no growth in 13-14 years between captures (Selman, Horne, Brauman, Jones, Seigel, and Qualls, unpubl. data).

Population Status. - Following Cagle's description of the species in 1954, no additional studies on the species' distribution in Mississippi were initiated until 1971. Cliburn (1971) collected G.flavimaculata throughout the Pascagoula, Chickasawhay (north to Stonewall, Clarke Co.), and Leaf rivers (north to Hot Coffee, Covington Co.), as well as Tallahala and Red creeks. No individuals were collected from the Bouie River or Black Creek. Cagle (1954) and Cliburn (pers. comm.) indicated that many streams, including the Bouie River, Tallahala Creek, and Bogue Homa Creek, were grossly polluted by industrial discharges during this time period and this could have negatively impacted Graptemys populations.

Later, McCoy and Vogt (1980) surveyed 25 localities throughout the drainage using sight and trapping census methods. They determined that the range of $G$.flavimaculata was the most restricted of the surveyed sawbacks (included G. oculifera and G. nigrinoda), with the range extending from the lower Pascagoula River in the vicinity of Vancleave (Jackson County), north in the Leaf River to Hot Coffee (Covington County), and north in the Chickasawhay River to Enterprise (Clarke County). They found the best populations of $G$. flavimaculata occurred from the Pascagoula River at Vancleave north to Hattiesburg in the Leaf River, but noted that only within portions of their range were there 'large thriving populations.' Populations were lower in the Chickasawhay River than in the Leaf River and they noted the water quality had decreased during their survey time on the Chickasawhay River (1977-1979), along with $G$. flavimaculata populations.

Boat surveys for G. flavimaculata were conducted by the U.S.Fish and Wildlife Service (Stewart 1989) along 54 river miles of the Leaf and Pascagoula rivers and 20 river miles of the Chickasawhay. These surveys found fewer than four turtles per river mile, with the largest population occurring between Wade and Vancleave (Jackson County). Following Federal listing as a Threatened species in 1991, an intense home range and population status study was conducted by Jones (1994) in the lower Pascagoula River. Using multiple techniques, population estimates for this population ranged between 72.8-370 turtles/river km.

Lindeman (1998, 1999) conducted basking surveys in multiple river drainages, including 21 localities within the Pascagoula River. Densities of all basking turtles were lower for the Pascagoula $(15.3 / \mathrm{km})$ than in the Pearl River (33.2/km). Graptemys flavimaculata accounted for $79 \%$ of the basking turtles observed, but were uncommon compared to other narrow headed species $(G$. oculifera and G. ouachitensis) surveyed in other drainages. Graptemys flavimaculata basking densities within the Pascagoula River ranged from 28-138/river km (mean 74), 0-29/km (mean
6) within the Chickasawhay River, and 0-20/km (mean 6) within the Leaf River. He also suggested a range reduction had occurred in the Leaf and Chickasawhay rivers. Lindeman (1999) concluded that there was a positive correlation with the amount of deadwood snags and the basking density of G. flavimaculata.

The most recent distributional surveys of Graptemys flavimaculata throughout the Pascagoula River drainage were conducted from 2006-08 (Selman and Qualls 2009a). The species was found at all historical drainage localities to the distributional limits originally described by Cliburn (1971), as well as new drainage localities (Bluff, Bogue Homa, Bouie, Buckatunna, Gaine's, Okatoma, and Thompson's creeks) and documented range expansions (Tallahala Creek and the Leaf River). Graptemys flavimaculata was the second most abundant basking turtle observed during bridge surveys, with Pseudemys concinna being the most abundant and G. gibbonsi being the third most abundant. At 23 sites (239.5 river $\mathrm{km}$ surveyed), the average basking density for G. flavimaculata was $24.8 / \mathrm{km}(0-139.2 / \mathrm{km})$; whereas, the average basking density for $G$. gibbonsi was $9.6 / \mathrm{km}(0-44.5 / \mathrm{km})$. The highest relative densities of $G$. flavimaculata were between Vancleave and Hattiesburg (23.7-139.2/km), as McCoy and Vogt (1980) had suggested. The upstream limit for G. flavimaculata in the Chickasawhay River was in the vicinity of Stonewall (Clarke County), as previously described by Cliburn(1971). However, upstream limits were farther north in the Leaf River to north of Taylorsville (Smith County), approximately 25.65 river km north of the previously known observed G. flavimaculata (Cliburn 1971). The species was also found to be present in smaller drainages than previously described for this species. However, the majority of G. flavimaculata occur in approximately $567 \mathrm{~km}$ of the Pascagoula $(99 \mathrm{~km})$, Leaf (219 $\mathrm{km}$ ), and Chickasawhay (249) rivers (Selman and Qualls 2009a). Assuming that these rivers average approximately $100 \mathrm{~m}$ wide (an overestimate) and that $G$. flavimaculata occurs within all $567 \mathrm{~km}$ of these rivers, then the maximum area occupied by this species is $<56.7 \mathrm{~km}^{2}$.

Population estimates for G. flavimaculata using markresight methods were conducted at three sites in 2005 and two sites from 2006-08 (Selman and Qualls 2008c, 2009a). In 2005, the Chickasawhay River site (south of Leakesville, Greene County) had an estimated 232 turtles in 2.4 river $\mathrm{km}(93 / \mathrm{km})$. From 2005-08, estimates for the Leaf River site (north of Hattiesburg, Forrest County) ranged between 261-451 (8-12/100 m). The lower Pascagoula River site (near Vancleave, Jackson County) was also surveyed from 2005-08 and population estimates ranged between 562-1203 in $2.0 \mathrm{~km}(28-61 / 100 \mathrm{~m})$. There was a significant decline (ca. $47 \%$ less) in the year following Hurricane Katrina, presumably due to the negative impacts, particularly related to water quality declines and associated loss of prey items (Selman and Qualls 2008c).

The lower Pascagoula River population of G. flavimaculata, which is the largest for the species, has become more vulnerable due to the negative impacts following 
Hurricane Katrina, as well as impacts of boat traffic on basking behavior. Furthermore, this population inhabits a more brackish environment than upstream populations, and could be negatively impacted by freshwater withdrawals or other changes that might increase salinity in this area. Other vulnerable populations include the Escatawpa and Bluff Creek populations, due to their small size, disjunct nature, high levels of boating recreation, and brackish habitat.

Threats to Survival. - The primary threat to the survival of $G$. flavimaculata is human impacts due to human population growth in southeast Mississippi. This species is still subject to direct human impacts, including: 1) shooting of turtles as target practice; 2) collisions with boats; 3 ) collection for the pet trade; 4) by-catch by fishermen; and 5) the destruction of nests on sandbars by recreational ATV riding. Furthermore, direct alterations of river habitat include: 1) the de-snagging of river systems (physical removal of deadwood); 2) channelization; and 3) excessive water withdrawal. Proposed private/government projects, particularly reservoirs for recreation/economic stimulus, could severely alter riverine habitat. Also, the number of humans using the Pascagoula River system as a recreational outlet has increased dramatically since the mid 1990s (Selman et al. 2007). The number of registered boats from Jackson County (the county with the highest densities of G. flavimaculata) in the last 22 years has increased $300 \%$ and, during this same time period, the percentage of small boats $(<16 \mathrm{ft})$ registered has decreased from $57 \%$ to $48 \%$, while the percentage of medium to large size boats (16-65 ft) registered has increased from 43-52\% (Selman 2010). Therefore, this indicates a trend of increasing boat traffic with larger boats that negatively impacts $G$. flavimaculata basking behavior and nesting habitat quality (Selman et al. 2007). Lastly, municipal/industrial effluents could degrade water quality and negatively impact prey items sensitive to water quality.

Several invasive/subsidized species are also threats to G. flavimaculata survival. Species present on nesting sandbars include cogon grass (Imperata cylindrica), nonnative cocklebur (Xanthium stramarium), and Chinese tallow tree (Triadica sebifera). These species impact nesting habitat by covering the highest parts of the sandbars, forcing turtles to nest in suboptimal areas that are more flood-prone. These invasive species also alter nest temperatures by shading the nest site, which could ultimately impact population demographics by altering sex ratios, since species of Graptemys exhibit temperature-dependent sex determination (Bull and Vogt 1979; Vogt and Bull 1984; Ewert and Nelson 1991). Two aquatic invasive plant species, water hyacinth (Eichhornia crassipes) and alligator weed (Alternanthera philoxeroides), have also been observed to impact $G$. flavimaculata basking behavior, as turtles avoided basking snags covered by these plants, but returned to bask once vegetation mats were removed (Selman et al. 2007). Lastly, invasive/subsidized predators, including the feral pig (Sus scrofa), the fish crow (Corvus ossifragus), and raccoon (Procyon lotor), are all nest predators and could have negative impacts on G. flavimaculata populations (Horne et al. 2003; Selman et al. 2007).

Conservation Measures Taken. - Graptemys flavimaculata was listed as Federally Threatened in 1991 (U.S. Fish and Wildlife Service 1991). Additionally, the species has been listed as Endangered by the State of Mississippi since 1975 (Mississippi Department of Wildlife, Fisheries, and Parks, 2000). Since Federal listing in 1991, several research projects were initiated and funded by U.S. Fish and Wildlife Service and Mississippi Department of Wildlife, Fisheries, and Parks to study the life history and ecology of G. flavimaculata. The highlights of these studies were presented above in the Habitat and Ecology section.

Protection of the Pascagoula River started in the 1970s, before the Federal listing of G. flavimaculata as Threatened, with the acquisition of the Pascagoula Hardwood Tract $(15,023$ ha) by The Nature Conservancy (TNC), which was thereafter transferred to the State of Mississippi as the Upper/ Lower Pascagoula Wildlife Management Area (WMA). Following the Federal listing, the U.S.Army Corps of Engineers (USACE) acquired Ward Bayou WMA(5355 ha) in the lower Pascagoula River to mitigate for environmental impacts due to the construction of the Tennessee-Tombigbee waterway. In 1999, TNC acquired an additional 1325 ha (Charles M. Deaton Preserve) north of the Pascagoula WMA and at the confluence of the Leaf and Chickasawhay Rivers. Also, TNC, along with the Department of Marine Resources and the Mississippi Secretary of State's Office, purchased an additional 4046 ha of the Pascagoula/Escatawpa marshlands that were designated as part of the Coastal Preserve System. Thereafter, in 2002, TNC purchased an additional 647 ha (Herman Murrah Preserve) that connected the Deaton Preserve and the Upper Pascagoula WMA. Currently, USACE is investigating the possibility of acquiring additional property for Ward Bayou WMA.

Graptemys flavimaculata occurs throughout this protected corridor (ca. $129 \mathrm{~km}$ ) and some of the largest populations are found in these areas, particularly in Ward Bayou and Lower Pascagoula WMAs. These areas provide high quality riparian habitat, which provide an abundance of deadwood for turtle basking sites. Additionally, the USACE has designated four nesting sandbars on Ward Bayou WMA off limits to human recreation during the $G$. flavimaculata nesting season (May 1 - October 31), as well as managing these sandbars for invasive species (i.e., cogon grass, cocklebur, and Chinese tallow tree).

Further conservation measures taken include a public outreach program initiated by the Mississippi Museum of Natural Science (MMNS). The primary role is to instruct children/students on endangered species of the Pascagoula River (including the Yellow-blotched Sawback) and surrounding habitats. During the fiscal year 2006-07, MMNS outreach instructed 11,886 children from counties within the Pascagoula River basin and there were 12,996 visitors to the Natural Science Museum from counties within the Pascagoula River basin. 
Conservation Measures Proposed. - The IUCN Red List Status is currently Vulnerable (VU), downlisted in 2011 from its previous listing of Endangered (EN). The downgrading of this status is justified due to the larger population estimates observed by Selman and Qualls (2009a) relative to other studies, as well as the range expansions and newly found localities that harbor this species. Water quality also seems to have improved over the last 15 years on the lower Leaf and Pascagoula Rivers as high numbers were found in areas by Selman and Qualls (2009a) that were previously void of the species. Furthermore, the state of Mississippi regards the species as Endangered (which provides legal protection from collection) and more protected riparian habitat has been preserved along the Pascagoula River system since its original Red Listing as Endangered. However, the status of Vulnerable remains due to the small range of this species, the large number of potential threats, and the significant declines of the largest population in the lower Pascagoula River following Hurricane Katrina. This population, as of 2009, has not recovered to 2005 levels (Selman and Qualls 2008c, 2009a).

All species of Graptemys, including G. flavimaculata, are listed by the USA on CITES Appendix III. They are currently being considered for potential uplisting to Appendix II.

Appropriate conservation measures for the Yellowblotched Sawback include protecting and improving habitat suitability of occupied rivers/creeks, which includes discouraging habitat alteration (i.e., de-snagging projects, impoundments, channelization), promoting streamside management zones and proper forest management practices within the drainage to private landowners, and controlling invasive species.Appropriateregulatory activities include law enforcement (to curtail illegal collection, shooting of turtles, and use of ATVson nesting sandbars), and limiting recreational use of the Pascagoula River to small or medium sized boats to prevent excessive wakes, which would limit turtle basking disturbance and erosion of nesting sandbars. Monitoring densities of existing populations should also be continued. Future areas that should be protected include the lower Escatawpa River, as well as extending the existing corridor along the Pascagoula River northwest and up the Leaf River. Additionally, property north of Hattiesburg on the Leaf River should be acquired, as this area supports the northernmost substantial population of G. flavimaculata in the Leaf River, as well as a sizeable population of G. gibbonsi.

Captive Husbandry. - There are several active breeding groups of G. flavimaculata in private collections and aquariums within the U.S. and abroad. In total, there are approximately 50-100 individuals in active breeding colonies in Europe, particularly within Austria and Germany (Walter Sachsse, pers. comm.). Within the USA, there are 100-200 in similar colonies, with the largest captive group at the Tennessee Aquarium (ca. 60 individuals), with some on loan to other institutions (Dave Collins, pers. comm.). These captive groups, however, are not actively pursuing maximum reproductive capacity (Dave Collins and Tom Mann, pers. comm.) due to in-situ, conservation efforts as previously outlined.
Graptemys flavimaculata is relatively hardy in captivity and tolerant of a wide range of housing practices, but the best results are achieved when housing, feeding, and proper nesting habitat closely resembles the natural environment (Paul Vander Schouw and Terry Majure, pers. comm.). Snaglike basking locations are preferred (e.g., logs, branches), as in the natural environment, but terrestrial basking is used if there are no snags available. Diet of captive individuals is primarily carnivorous and individuals will accept various commercial pellet food (including turtle sticks, spirulina pellets, fish pellets), crickets, earthworms, bloodworms, blackworms, beef heart, krill, pinky mice, lettuce, and duckweed. Feeding, courtship, copulation, and nesting seem to occur most frequently during the morning and late afternoon/early evening prior to sunset (Paul VanderSchouw, pers. comm.). In captivity, females prefer clean sandy areas for nesting; they are quite wary during captive nesting and will abandon the attempt if disturbed.

Current Research. - Studies on the impact of recreational boating on behavior/physiology (including hematological studies) are nearing completion (W. Selman, The University of Southern Mississippi). Further, geographic variation in demography and morphological variation is currently in preparation (W. Selman).

Future research should focus on regularly assessing marked populations at established sites (Hattiesburg, Leakesville, and Vancleave) to determine population density/ viability, demography, growth, long-term movements, and longevity of $G$. flavimaculata. Additionally, future work should evaluate the size of the Escatawpa population, as well as its connectivity/isolation to the Pascagoula River population. Research should also extend to populations within smaller rivers and drainages to determine the viability/ connectivity of these populations, as well as the ecology of upriver populations, since much work has been devoted to the lower Pascagoula population.

Remarks. - The use of the common name 'Yellowblotched Sawback' has been partially lost since the Society for the Study of Amphibians and Reptiles formally listed the common name of this species as the 'Yellow-blotched Map Turtle.' However, there is historical and recent support to continue the use of 'sawback' as an accepted common name for this species. First, this was the original name used in the species description by Cagle (1954). Second, Weins et al. (2010) recovered all three sawback species ( $G$.flavimaculata, $G$. oculifera, and G. nigrinoda) as a monophyletic clade within the genus Graptemys. Lastly, it is a more descriptive name in the field and has utility when explaining their appearance to people unfamiliar with "map turtles." Recently, other researchers, including P. Lindeman, have supported the retention of this name, including in a recent book on all Graptemys (Lindeman, in press).

Acknowledgments. - We would like to thank DaveCollins, Walter Sachsse, and Paul Vander Schouw for comments regarding the status and maintenance of captive groups of G. flavimaculata. 


\section{LITERATURE CITED}

BADER, B. 1976. A turtle paradise. St. Louis Herpetological Society Newsletter 3:7-9.

BRAUMAN, R.J. 1995. The female reproductive biology, nesting habits, and conservation biology of the yellow-blotched map turtle, Graptemys flavimaculata. Master's Thesis, Southeastern Louisiana University, Hammond, Louisiana.

BRAUMAN,R.J.ANDFIORILLO,R.A. 1995.Lampropeltis getulaholbrooki (Speckled Kingsnake). Oophagy. Herpetological Review 26:101.

Buhlmann, K.A.,Akre,T.S.B.,Iverson,J.B., Karapatakis, D., MitTERMEIER, R.A., GEORGES, A., RHODIN, A.G.J., vAN DiJK, P.P., AND GibBons, J.W. 2009. A global analysis of tortoise and freshwater turtle distributions with identification of priority conservation areas. Chelonian Conservation and Biology 8(2):116-149.

BuLl, J.J. AND VoGt, R.C. 1979. Temperature-dependent sex determination in turtles. Science 206:1186-1188.

Cagle, F.R. 1954. Two new species of the genus Graptemys. Tulane Studies in Zoology 1:167-186.

Cliburn, J.W. 1971. The ranges of four species of Graptemys in Mississippi. Journal of Mississippi Academy of Sciences 16:16-19.

EnNen, J.R., Kreiser, B.R., Qualls, C.P. And Lovich, J.E. 2010. Morphological and molecular reassessment of Graptemys oculifera and Graptemys flavimaculata (Testudines: Emydidae). Journal of Herpetology 44:544-554.

ERnst, C.H. And Lovich, J.E. 2009. Turtles of the United States and Canada. 2nd Ed. Baltimore, MD: The Johns Hopkins University Press.

Ewert, M.A. AND Nelson, C.E. 1991. Sex determination in turtles: diverse patterns and some possible adaptive values. Copeia 1991:50-69.

FLOYD, P. 1973. Singing River sawbacks. International Turtle and Tortoise Society Journal 7:8-10.

HERTWIG, S. 2001. Ökologie,Haltung und Fortpflanzung im Terrarium von Graptemys caglei, G. flavimaculata, G. nigrinoda nigrinoda und G. oculifera. Salamandra 37:21-48.

Horne, B. 1999. Female reproductive ecology and experimental manipulation of nest site vegetation: implications for the conservation of theyellow-blotched mapturtle(Graptemysflavimaculata).Master's Thesis, Southeastern Louisiana University, Hammond, LA.

Horne,B.,Brauman,R.,Moore,M., ANDSEIGEL,R.2003.Reproductive and nesting ecology of the yellow-blotched map turtle, Graptemys flavimaculata: implications for conservation and management. Copeia 2003:729-738.

Iverson, J.B. 1992. A Revised Checklist with Distribution Maps of the Turtles of the World. Richmond, IN: Privately published, $363 \mathrm{pp}$.

JoNES, R.L. 1994.Density, population structure, and movements of the yellow-blotched mapturtle(Graptemysflavimaculata).Unpublished report to U.S. Fish and Wildlife Service and the Mississippi Department of Wildlife, Fisheries, and Parks, Jackson, MS.

JONES, R.L. 1996. Home range and seasonal movements of the turtle Graptemys flavimaculata. Journal of Herpetology 30:376-385.

Kannan, K., Ueda, M., Shelby, J.A., Mendonça, M.T., Kawano, M., Matsuda, M., Wakimoto, T., AND GiEsy, J.P. 2000. Polychlorinated dibenzo-p-dioxins (PCDDs), dibenzofurans (PCDFs), biphenyls (PCBs), and organochlorine pesticides in yellow-blotched map turtle from the Pascagoula River basin, Mississippi, USA. Archives of Environmental Contamination and Toxicology 38:362-370.

KILLEBREw, F.C. 1979. Osteological variation between Graptemys flavimaculata and Graptemys nigrinoda (Testudines: Emydidae). Herpetologica 35:146-153.

Krysko, K.L, Enge, K.M., Donlan, E.M., Golden, E.A., Burgess,
J.P. AND LARSON, K.W. 2010. The non-marine herpetofauna of Key Biscayne, Florida. Herpetological Conservation and Biology 5:132-142.

Lamb, T., Lydeard, C., Walker, R.B., and Gibbons, J.W. 1994. Molecular systematics of map turtles (Graptemys): a comparison of mitochondrial restriction site versus sequence data. Systematic Biology 43:543-559.

LiNDEMAN, P.V. 1998. Of deadwood and map turtles (Graptemys): an analysis of species status for five species in three river drainages using replicated spotting-scope counts of basking turtles. Linnaeus Fund research report. Chelonian Conservation and Biology 3:137-141.

LindEMAN, P.V. 1999. Surveys of basking map turtles Graptemys spp. in three river drainages and the importance of deadwood abundance. Biological Conservation 88:33-42.

Lindeman, P.V.In Press. The Map Turtle and Sawback Atlas: Ecology, Evolution, Distribution, and Conservation of the Genus Graptemys. Norman, OK: University of Oklahoma Press.

McCoy, C.J. And Vogt, R.C. 1980. Distribution and population status of the ringed sawback turtle (Graptemys oculifera), blotched sawback (Graptemys flavimaculata), and black-knobbed sawback (Graptemys nigrinoda) in Alabama and Mississippi. USFWS Contract No. 14-16-0004-79-038.

McCoy, C.J. AND Vogt, R.C. 1987. Graptemys flavimaculata Cagle Yellow-blotched Sawback. Catalogue of American Amphibians and Reptiles 403.1-403.2.

Mississippi Department of Wildlife, Fisheries, and Parks. 2000. Endangered Species of Mississippi. Public Notice No. 3357.001. Mississippi Department of Wildlife, Fisheries, and Parks, Jackson, MS, 4 pp.

Moore, M.J.C. 2003. Behavioral ecology of the threatened yellowblotched map turtle (Graptemys flavimaculata): implications for conservation and management. Masters Thesis, Southeastern Louisiana University, Hammond, LA.

Moore, M.J.C. AND Seigel, R.A. 2006. No place to nest or bask: effects of human disturbance on the nesting and basking habits of yellow-blotched mapturtles (Graptemysflavimaculata).Biological Conservation 130:386-393.

Seigel, R.A. AND Brauman, R.J. 1994. Food habits of the yellowblotched map turtle(Graptemysflavimaculata). Technical report no. 28. Mississippi Museum of Natural Science, Jackson, MS, 17 pp.

Selman, W. 2010. Conservation and ecology of the yellow-blotched sawback (Graptemys flavimaculata). Ph.D. Thesis, University of Southern Mississippi, Hattiesburg, MS.

Selman, W. ANDQualls, C.2005. Steroid hormone levels and reproduction in the yellow-blotched sawbackturtle(Graptemysflavimaculata) and the congeneric ringed sawback turtle (Graptemys oculifera). Technical report to the Mississippi Department of Wildlife, Fisheries, and Parks. Jackson, MS, 33 pp

Selman, W. and Qualls, C. 2006. Steroid hormone levels and current population status of the yellow-blotched sawback turtle (Graptemys flavimaculata). Technical report to the Mississippi Department of Wildlife, Fisheries, and Parks. Jackson, MS, 58 pp.

SELMAN, W. ANDQuALls, C. 2008a. Graptemys flavimaculata (Yellowblotched Map Turtle). Foraging Behavior. Herpetological Review 39:215.

Selman, W. And Qualls, C.2008b.Graptemys flavimaculata (Yellowblotched Map Turtle). Interspecific basking site competition. Herpetological Review 39:214-215.

Selman, W. and Qualls, C. 2008c. The impacts of Hurricane Katrina on apopulation of yellow-blotched sawbacks(Graptemysflavimaculata) in the Lower Pascagoula River. Herpetological Conservation and Biology 3:224-230.

Selman, W. and Qualls, C. 2009a. Distribution and population status 
of two imperiled Graptemys species of the Pascagoula River system. Herpetological Conservation and Biology 4:171-184.

SElman, W. ANDQualls,C.2009b.Graptemys flavimaculata (Yellowblotched Map Turtle). Basking and parasite removal.Herpetological Review 40:78-79.

Selman, W. AND Qualls, C. 2011. Basking ecology of the Yellowblotched Sawback (Graptemys flavimaculata), an imperiled turtle species of thePascagoulaRiver system,Mississippi,USA.Chelonian Conservation and Biology 10:188-197.

Selman, W., Qualls, C., And Mendonça, M. 2007. Assessment of the impact of Hurricane Katrina on the yellow-blotched sawback (Graptemys flavimaculata): Year 1. Technical report to the Mississippi Department of Wildlife, Fisheries, and Parks and the U.S. Fish and Wildlife Service. Jackson, MS, 73 pp.

Selman,W.,Ennen,J.,Kreiser,B.,ANDQualls, C.2009.Cross-species amplification of emydid microsatellite loci in three Graptemys species and their utility as a conservation tool. Herpetological Review 40:32-37.

SHELBy, J.A. AND MENDONÇA, M.T. 2001. Comparison of reproductive parameters in male yellow-blotched map turtles (Graptemys flavimaculata) from a historically contaminated site and a reference site. Comparative Biochemistry and Physiology Part C 129:233-242.

Shelby, J.A., Mendonca, M.T., Horne, B.D., AND Seigel, R.A. 2000. Seasonal variation in reproductive steroids of male and female yellow-blotch map turtles, Graptemys flavimaculata. General and Comparative Endocrinology 119:43-51.

Shelby-Walker, J.A., Ward, C.K., and MendonçA, M.T. 2009. Reproductive parameters in female yellow-blotched map turtles (Graptemys flavimaculata) from a historically contaminated vs. a reference site. Comparative Biochemistry and Physiology, Part A 154:401-408.
SteInAUER, M.L. And Horne, B.D. 2002. Enteric helminths of Graptemys flavimaculata Cagle, 1954, a threatened chelonian species from the Pascagoula River in Mississippi, U.S.A. Comparative Parasitology 69:219-222.

StewART, J.H. 1989. Status review of yellow-blotched map turtle, Graptemys flavimaculata. Unpublished report to the U.S. Fish and Wildlife Service, Jackson, MS.

U.S. Fish and WildLIFE SERVICE. 1991. Threatened status for the yellow-blotched map turtle, Graptemys flavimaculata. Federal Register 56:1459-1463.

Vogt, R.C. AND Bull, J.J. 1984. Ecology of hatchling sex ratios in map turtles. Ecology 65:582-587.

WAHLQUIST,H. 1970. Sawbacks of the Gulf Coast. International Turtle and Tortoise Society Journal 4(4):10-13, 28.

Weins, J.J., Kuczynski, C.A., AND StePhens, P.R. 2010. Discordant mitochondrial and nuclear gene phylogenies in emydid turtles: implications for speciation and conservation. Biological Journal of the Linnaean Society 99:445-461.

\section{Citation Format for this Account:}

Selman, W. And Jones, R.L. 2011. Graptemys flavimaculata Cagle 1954-Yellow-Blotched Sawback, Yellow-Blotched MapTurtle. In: Rhodin, A.G.J., Pritchard, P.C.H., van Dijk, P.P., Saumure, R.A., Buhlmann, K.A., Iverson, J.B., and Mittermeier, R.A. (Eds.).Conservation Biology of Freshwater Turtles and Tortoises: ACompilation Project of the IUCN/SSC Tortoise and Freshwater Turtle Specialist Group. Chelonian Research Monographs No.5, pp.052.1-052.11, doi:10.3854/crm.5.052.flavimaculata.v1.2011, http://www.iucn-tftsg.org/cbftt/. 